\title{
Sir John Herbert Parsons
}

We feel that it is only right that some special notice should be taken in this Journal of one name that appeared in the list of New Year's honours.

In the world of ophthalmology few names are better known than that of John Herbert Parsons. We who have been associated with him in editing the British Jogral of Ophthalmologr

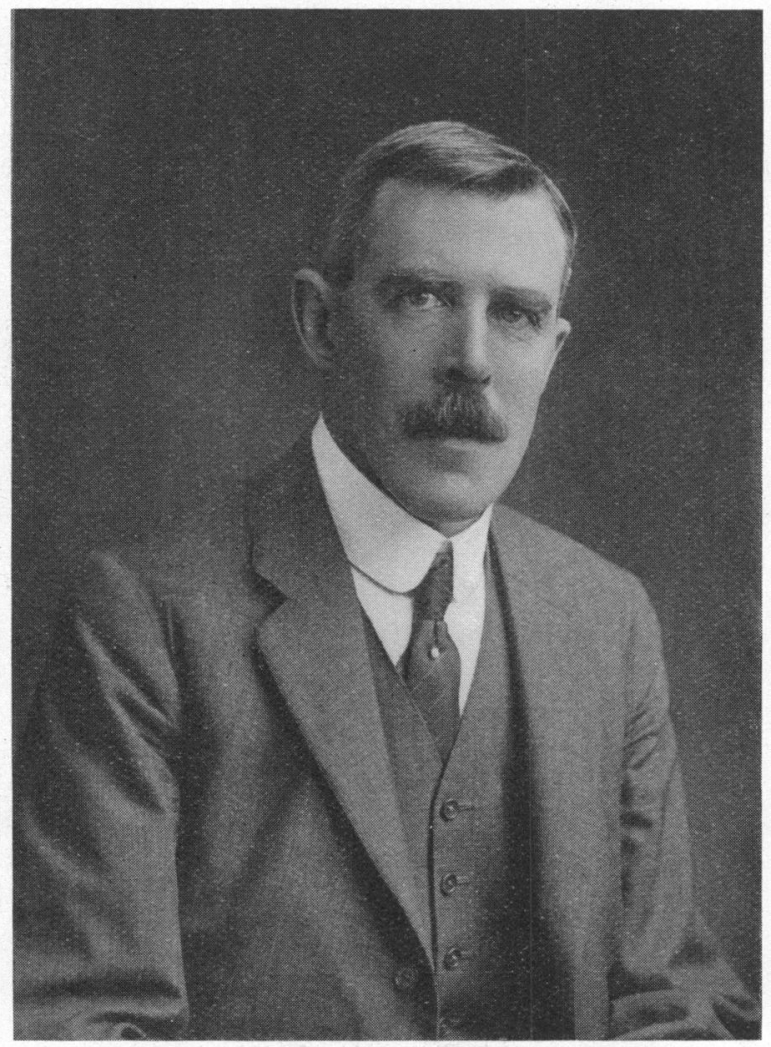

Sir John Herbert Parsons

know how much he has done for it since its foundation, and how valuable his services have been as Chairman of the Editorial Committee.

$\mathrm{He}$ is one of the founders of the Council of British Ophthalmologists, and one of its most active members.

It would be hard to find any one who has devoted so much time to arduous work on committees appointed by various Government departments and public bodies. Amongst the important posts 
he has held, the following may be mentioned:-When the Royal Society was requested by the Government to study the question of glassworkers' cataract, Parsons was appointed a member of the committee, and was its secretary. He was a member of the Departmental Committee on Sight Tests appointed by the Board of Trade, and served this Department nine years as examiner for the special sight tests examinations for the Mercantile Marine. $\mathrm{He}$ was also member of the Departmental Committee on Factory Lighting appointed by the Home Office. During the war, after first acting as Captain in the R.A.M.C., he was promoted to be Colonel in the Army Medical Service as Consulting Ophthalmic Surgeon to the Forces, and still serves the War Office as a member of the Appeal Board for Sandhurst and Woolwich Cadets, and the Air Ministry as a member of the Advisory Medical Council. He was the representative of the Royal College of Surgeons at the Conference called by Scotland Yard to advise on the sight tests for motor drivers.

$\mathrm{He}$ is the Chairman of the Committee of the Illuminating Engineering Society to advise the London County Council on the Lighting of Cinemas, and is the representative of the Royal College of Surgeons on the Departmental Committee appointed by the Ministry of Health on the Causes and Prevention of Blindness.

But it is especially his work on more purely ophthalmic lines that has given him his wide-spread reputation. His well-known Pathology of the Eye is alone in its class, and his treatise on Colour Vision is by far the soundest and most scientific work on the subject in the English language, while his Text Book of Ophthalmology is a prime favourite among medical students of the present day.

Last May he was made a Fellow of the Royal Society, and the recent honour of Knighthood conferred on him is one which will gratify everyone who knows him.

\section{ABSTRACTS}

\section{I-LIGHTING IN FACTORIES AND WORKSHOPS}

Second report of the Departmental (Home Office) Committee on Lighting in Factories and Workshops. London: H.M. Stationery Office.

The Committee on lighting in factories and workshops, originally appointed in 1913, has recently issued a second report. The first interim report appeared in 1915 and dealt with the question 